\title{
Phytotoxic Activity of Parthenium Against Wheat and Canola Differ With Plant Parts and Bioassays Techniques ${ }^{1}$
}

\author{
A Atividade Fitotóxica de Parthenium contra Trigo e Canola Difere com Partes de Plantas e \\ Técnicas de Bioensaios
}

\author{
KHALIQ, A. ${ }^{2}$, ASLAM, F. ${ }^{2}$, MATLOOB, A..$^{2,3}$, JAVAID, A. ${ }^{4}$, TANVEER, A. ${ }^{2}$, HUSSAIN, ${ }^{5}{ }^{5}$, and \\ IHSAN, M.Z. ${ }^{6}$
}

\begin{abstract}
Phytotoxic effects of invasive weed Parthenium hysterophorus were studied by using whole plant, leaf and root aqueous extracts at $0,2.5,5.0,7.5$ and $10 \%(\mathrm{w} / \mathrm{v})$ concentrations against germination and early seedling growth of wheat and canola. Studies were carried out both in Petri plates with filter paper as substratum placed in controlled conditions and soil-filled plastic pots placed in open environments. Pronounced variation was noted for phytotoxic activity of different plant parts of parthenium, aqueous extract concentrations, test species, and bioassay techniques. Aqueous parthenium extracts either inhibited or delayed the germination and suppressed seedling growth of test species over control. For both test species, all the germination attributes were suppressed to a greater extent in Petri plates than in plastic pots. Leaf extracts were more suppressive to germination of test species than whole plant and root extracts. Increasing extract concentration beyond $2.5 \%$ caused significant reduction in seedling dry biomass of both test species. Aqueous parthenium extract diminished chlorophyll contents of wheat and canola by $32-63 \%$ and $29-69 \%$, respectively. Nevertheless, an increase of $9-172 \%$ and $22-60 \%$ in phenolic contents of wheat and canola was recorded. Canola appeared to be more susceptible than wheat at all extract concentrations. Present study concluded that bioassays conducted under controlled condition using filter paper as substratum may be misleading due to over estimation of allelopathic response and variation in potential of receiver and donor species. Furthermore, it implies that threshold concentrations of allelochemicals for test species in Petri plates are rarely reached under field conditions.
\end{abstract}

Keywords: allelopathic inhibition, aqueous extracts, bioassay techniques, germination dynamics, parthenium, phenolics, seedling growth.

\begin{abstract}
RESUMO - Foram estudados os efeitos fitotóxicos da planta daninha invasora Parthenium hysterophorus, por meio de extratos aquosos de plantas integrais, folhas e raizes em concentrações de $0,2,5,5,0,7,5$ e 10\% (w/v), sobre a germinação e o crescimento inicial de plântulas de trigo e canola. Foram realizados estudos tanto em placas de Petri com papel-filtro quanto em substrato colocado em condições controladas e vasos de plástico cheios de solo colocados em ambientes abertos. Variação pronunciada foi observada na atividade fitotóxica de diferentes partes da planta Parthenium, nas concentrações de extrato aquoso, na espécie de teste e nas técnicas de bioensaio. Extratos aquosos de Parthenium inibiram ou retardaram a germinação e o crescimento suprimido de plântulas das espécies de teste, em relação ao controle. Para ambas as espécies de teste, todos os atributos de germinação foram suprimidos em uma extensão maior em placas de Petri do que em vasos de plástico. Os extratos de folhas foram mais supressivos à germinação de espécies de teste do que as plantas integrais e os extratos de raizes. O aumento da concentração do extrato além de $2,5 \%$ causou redução significativa na biomassa seca de plântulas nas duas espécies de teste. $O$ extrato aquoso de Parthenium diminuiu os teores de clorofila em trigo e canola em 32-63\% e 29-69\%, respectivamente. No entanto, aumentos de 9-172\% e 22-60\% em conteúdo fenólico de trigo e canola
\end{abstract}

Recebido para publicação em 4.9.2015 e aprovado em 5.10.2015.

2 University of Agriculture, Faisalabad-Pakistan, $<$ khaliquaf@gmail.com $>{ }^{3}$ Muhammad Nawaz Shareef University of Agriculture, Multan, Pakistan; ${ }^{4}$ University of the Punjab, Quaid-e-Azam Campus, Lahore, Pakistan; ${ }^{5}$ Huazhong Agricultural University, Wuhan, Hubei 430070, China < shussain@webmail.hzau.edu.cn>; ${ }^{6}$ King Abdulaziz University, Jeddah, Saudi Arabia.

Planta Daninha, Viçosa-MG, v. 34, n. 1, p. 11-24, 2016 
foram registrados. A canola pareceu ser mais suscetivel do que o trigo a todas as concentrações do extrato. Concluiu-se que bioensaios realizados sob condições controladas, utilizando papel-filtro como substrato, podem ser enganosos devido à sobrestimação da resposta alelopática e variação no potencial das espécies receptoras e doadoras. Além disso, isso sugere que os limites de concentrações de aleloquimicos para as espécies de teste em placas de Petri raramente são atingidos em condições de campo.

Palavras-chave: inibição alelopática, extratos aquosos, técnicas de bioensaios, dinâmica de germinação, parthenium, compostos fenólicos, crescimento de plântulas.

\section{INTRODUCTION}

Parthenium (Parthenium hysterophorus) is an aggressive and troublesome weed with a strong invasive potential (Javaid et al., 2011). Although native to tropical America (Picman \& Picman, 1984), its infestation has remarkably increased during the last 20-30 years in both cropped and non-cropped areas in Pakistan (Marwat et al., 2008; Khaliq et al., 2015). It has been recognized as a serious weed responsible for loss of crop productivity, fodder scarcity, biodiversity depletion and adverse effects on animal and human health (Tefera, 2002; Singh et al., 2005; Javaid \& Riaz, 2012). The rapid expansion and widespread distribution of this weed is a challenging threat to the productivity and sustainability of agro-ecosystems. The success of this weed as an invader has been attributed to rapid growth, high fecundity, greater acclimatization potential and, above all, interference by resource depletion and allelopathy (Marwat et al., 2008).

Allelopathy is a mechanism through which weeds often affect the germination dynamics and growth of field crops (Qasem \& Foy, 2001) and promote weedy monocultures by influencing species patterning in agroecosystems (Weston \& Duke, 2003). Release of allelochemicals by living as well as dead weed tissues left in the soil after the completion of life cycle has deleterious effects on the same or subsequent plants (Batish et al., 2002; Khaliq et al., 2013a; Khaliq et al., 2015). Allelochemicals are reported to be present in almost all plant parts, including stems, leaves, flowers, buds, pollen grains, seeds, fruits, roots and rhizomes (Qasem \& Foy, 2001). Differences are also observed amongst species regarding their allelopathic potential and abilities to produce toxins in various plant parts
(Qasem \& Foy, 2001; Khaliq et al., 2013b). Allelopathic interference by parthenium is well documented and almost all plant parts, including pollen and trichomes, are known to possess a number of water-soluble allelochemicals predominantly as phenolic acids and sesquiterpene lactones (Kohli et al., 2006; Aslam et al., 2014).

Bioassays are widely used to demonstrate allelopathy due to their usefulness as an early proof of allelopathic activity, low cost involved, easy execution and replication (Inderjit \& Weston, 2000). Evaluating the influence of allelopathic extract on the germination and seedling growth of test species has been the most widely used technique for such bioassays. However, contrary to bioassay studies, the suppression achieved under field conditions is often negligible (Duke et al., 2001), and results vary under controlled and natural conditions (Inderjit \& Weston, 2000) merely because an array of factors interact either simultaneously or sequentially under field conditions. Bioassays conducted under controlled conditions using filter paper as a substratum can be misleading due to an overestimation of the allelopathic response and the potential of the receiver and donor species. Inderjit \& Weiner (2001) have asserted that, in order to achieve a better understanding of the subject matter, allelopathy should be conceptualized in terms of soil ecology. Without soil, any growth bioassay can be misleading with a little or no ecological relevance (Foy, 1999). Parthenium is getting increasing significance as a noxious invasive weed. Despite the availability of the volumetric literature on the allelopathic potential of this weed (Mersie \& Singh, 1988; Swaminathan et al., 1990; Tefera, 2002; Rashid et al., 2008; Aslam et al., 2014) and foregoing research, results are difficult to be generalized and 
implemented under field conditions as many of these studies were conducted under control conditions neglecting the components of the natural setting.

The present work attempts to explore the phytotoxic potential of parthenium against crops of economic significance. The objectives were to ascertain (1) whether aqueous extracts of different parts of parthenium affect the germination and growth of wheat and canola, and to what extent under controlled conditions, (2) whether soil application of these extracts under open environments produces the same results in pot experiments, and (3) to rank the different plant parts for their phytotoxic potential and test species in terms of susceptibility.

\section{MATERIALS AND METHODS}

\section{Preparation of extract}

Field grown plants of parthenium were collected at flowering stage and respective fractions (whole plant, leaves and roots) were separately dried in the shade. These were chopped into $2-3 \mathrm{~cm}$ pieces and oven dried at $50{ }^{\circ} \mathrm{C}$ for $48 \mathrm{~h}$. These were separately ground and passed through a 40 mesh screen. Ground powder was soaked in distilled water at $10 \mathrm{~g} 100 \mathrm{~mL}$ for $24 \mathrm{~h}$ at room temperature $\left(25 \pm 2{ }^{\circ} \mathrm{C}\right)$. The filtrates of the respective plant fractions were obtained after passing the mixture through a Whatman \# 42 filter paper. These extracts were designated as $10 \% \mathrm{w} / \mathrm{v}$ stock solutions. These were used either as such or diluted with distilled water to prepare lower concentrations of 2.5, 5.0 and $7.5 \%$.

\section{Biochemical attributes of aqueous extracts}

The $\mathrm{pH}$ and electrical conductivity (EC) of different concentrations of the aqueous extracts of different parts of parthenium were worked out using a digital $\mathrm{pH}$ and a conductivity meter (HI-9811, Hannah, USA). The osmotic potential was determined using the following formula:

Osmotic potential $(-\mathrm{Mpa})=\mathrm{EC}\left(\mathrm{ds} \mathrm{m}^{-1}\right) \times-0.036$

Total water-soluble phenolics in aqueous parthenium extracts were quantified as per Swain \& Hillis (1959) using Folin-Ciocalteu's reagent and expressed as ferullic acid equivalent as it has been reported to be a major allelochemical in parthenium tissues (Singh et al., 2005). Measurements were taken by repeating the whole procedures twice, and average values are given in Table 1 .

\section{Lab experiment: Influence of aqueous extracts of parthenium on germination of wheat and canola in Petri plates}

Aqueous extracts of whole plant, leaves and roots of parthenium at different concentrations viz., $0,2.5,5.0,7.5$ and $10.0 \%$ were evaluated for their effects on the germination of wheat and canola. Fifteen surface sterilized seeds of test species were evenly placed between two layers of Whatman

Table 1 - Chemical properties of different concentrations of aqueous parthenium extracts

\begin{tabular}{|c|c|c|c|c|c|}
\hline $\begin{array}{l}\text { Parthenium plant } \\
\text { fractions }\end{array}$ & $\begin{array}{c}\text { Extract } \\
\text { concentration } \\
(\%)\end{array}$ & $\mathrm{pH}$ & $\mathrm{EC}\left(\mathrm{ds} \mathrm{m}^{-1}\right)$ & $\begin{array}{c}\text { Osmotic } \\
\text { potential } \\
(-\mathrm{MPa})\end{array}$ & $\begin{array}{l}\text { Total soluble phenolics } \\
\qquad\left(\mu \mathrm{g} \mathrm{ml}^{-1}\right)\end{array}$ \\
\hline \multirow{4}{*}{ Whole plant } & 2.5 & 6.8 & 1.43 & 0.05 & 74.21 \\
\hline & 5.0 & 6.7 & 2.63 & 0.09 & 220.53 \\
\hline & 7.5 & 6.6 & 3.69 & 0.13 & 312.11 \\
\hline & 10.0 & 6.6 & 4.69 & 0.17 & 510 \\
\hline \multirow{4}{*}{ Leaf } & 2.5 & 7.8 & 1.55 & 0.06 & 503.68 \\
\hline & 5.0 & 7.5 & 3.07 & 0.11 & 817.37 \\
\hline & 7.5 & 7.5 & 4.43 & 0.16 & 1047.89 \\
\hline & 10.0 & 7.1 & 5.63 & 0.20 & 1345.76 \\
\hline \multirow{4}{*}{ Root } & 2.5 & 7.7 & 1.05 & 0.04 & 0.53 \\
\hline & 5.0 & 7.5 & 2.07 & 0.07 & 33.16 \\
\hline & 7.5 & 7.5 & 3.15 & 0.11 & 39.47 \\
\hline & 10.0 & 7.2 & 4.06 & 0.15 & 125.79 \\
\hline
\end{tabular}


\# 42 filter paper in sterilized Petri plates (9 $\mathrm{cm}$ diameter). Extract of the respective extract fraction $(5 \mathrm{~mL})$ and concentration was added to each Petri plate while the same volume of distilled water was applied in the control treatment. Half of the extract was used for moistening the filter paper receiving the seeds, while the remaining was applied to the covering filter paper (Khaliq et al., 2013b). Germination counts were recorded on a daily basis according to AOSA (1990) until a constant count was achieved. Seeds were considered to be germinated when radicle and hypocotyl length was over $2 \mathrm{~mm}$. Time taken to $50 \%$ germination of seedling $\left(\mathrm{T}_{50}\right)$ was calculated according to the modified formula of Farooq et al. (2005) as below:

$$
\mathrm{T}_{50}=\mathrm{t}_{\mathrm{i}}+\frac{\left(\frac{\mathrm{N}}{2}-\mathrm{n}_{\mathrm{i}}\right)\left(\mathrm{t}_{\mathrm{j}}-\mathrm{t}_{\mathrm{i}}\right)}{\mathrm{n}_{\mathrm{j}}-\mathrm{n}_{\mathrm{i}}}
$$

$\mathrm{N}$ is the final number of germinated seeds, and $n_{i}$ and $n_{j}$ are the cumulative numbers of seeds germinated by adjacent counts at times $t_{i}$ and $t_{j}$ where $n_{i}<N / 2<n_{j}$. Mean germination time (MGT) was calculated according to Ellis \& Robert (1981):

$$
\text { MGT }=\frac{\sum \mathrm{Dn}}{\sum \mathrm{n}}
$$

where $\mathrm{n}$ is the number of seeds, which were germinated on day $\mathrm{D}$, and $\mathrm{D}$ is the number of days counted from the beginning of germination. Germination index (GI) was calculated as described by AOSA (1983):

$$
\begin{aligned}
G I= & \frac{\text { No. of germinated seeds }}{\text { Days of first count }}+--- \\
& +\frac{\text { No. of germinated seeds }}{\text { Days of final cout }}
\end{aligned}
$$

\section{Screen house experiment: Influence of soil-applied aqueous extracts of parthenium on emergence, seedling growth and biochemical attributes of wheat and canola}

\section{Pot bioassays}

Fifteen surface sterilized seeds of both test species were sown in separate themocol trays measuring $18 \times 14 \mathrm{~cm}$ filled with air dried and well mixed field soil (750 g). Soil belongs to the Lyallpur soil series (Aridisol-fine-silty, mixed, hyperthermic Ustalfic, Haplargid in the USDA classification, and Haplic Yermosols in the FAO classification). The $\mathrm{pH}$ of the saturated soil paste and EC of the saturation extract were 7.6 and $0.41 \mathrm{dS} \mathrm{m}^{-1}$, respectively. Aqueous extracts $(10 \mathrm{~mL})$ of different parthenium fractions (whole plant, leaves and roots) at different concentrations $(2.5,5.0,7.5$ and $10 \%)$ were applied just after sowing the seeds. The pots with distilled water application were maintained as control. These pots were placed in a screen house under natural conditions with $11 / 13 \mathrm{~h}$ light/dark period. Pots were subsequently irrigated as and when required to keep the soil moist and to avoid water stress.

The emergence data were collected on a daily basis (AOSA, 1990) and were used to compute different attributes of emergence as time to start emergence (TSE), time taken to $50 \%$ emergence $\left(\mathrm{E}_{50}\right)$, mean emergence time $(\mathrm{MET})$, emergence index (EI) and final emergence percentage (FEP) as described in a previous section. Two weeks after the emergence, seedlings were uprooted and root and shoot length were determined with a measuring tape. Seedling roots and shoots from each pot were oven dried separately at $70{ }^{\circ} \mathrm{C}$ for $48 \mathrm{~h}$ and weighed thereafter. Total seedling biomass was calculated as the sum of the biomass of root and shoot.

\section{Biochemical analyses}

Seedling fresh tissue (leaf) was used for determination of total soluble phenolics (Randhir \& Shetty, 2005) that were expressed as gallic acid equivalents. Photosynthetic pigments (chlorophyll contents) were extracted in ice cold acetone $(80 \%)$ and read out at 663 and $645 \mathrm{~nm}$ wavelength in a UVspectrophotometer (UV-4000, ORI, Germany). These are expressed as $\mathrm{mg} \mathrm{g}^{-1}$ fresh leaf weight (Lichtenthaler, 1987). Determinations were made as per treatment and replications.

\section{Experimental design and statistical analyses}

All the experiments were conducted using a completely randomized design with four 
replications and repeated once. Results of both repeats were similar; hence, the data were pooled and averaged thereof. Data were analyzed following analysis of variance using Statistix 8.1 (Analytical Software, Tallahassee, FL, USA) software. The differences between treatments were separated using the Least Significance Difference (LSD) test at 0.05\% probability level. Graphical presentation and regression analysis were made using Sigma plot (Systat Software Inc., San Jose, CA, USA).

\section{RESULTS}

\section{Experiment-I: Influence of aqueous extracts of parthenium on the germination of wheat and canola in Petri plates}

Pronounced variations in germination attributes of wheat and canola were observed under the influence of parthenium extract fractions and aqueous extract concentration (Figure 1). Higher concentrations $(7.5 \%$ and $10 \%$ ) of all the extract fractions delayed time to start germination (TSG) of both test species up to one and a half day but such a delay was insignificant at a lower extract $(2.5 \%)$ concentration (Figure 1). Whole plant, leaf and root extracts of parthenium had a significant bearing on $\mathrm{T}_{50}$ in canola, while $\mathrm{T}_{50}$ of wheat was affected only by extract concentration (Table 2). Maximum delay in $\mathrm{T}_{50}$ was observed at the highest extract concentration (10\%). Interactive effect of extract fractions with concentration was also significant $(p \leq 0.05)$ for MGT. Significant interaction implied that at lower concentrations (2.5-5\%), leaf extract was more suppressive than whole plant and root extract. Nevertheless, MGT of wheat did not vary significantly between whole plant and leaf aqueous extract of parthenium. For canola, significantly higher MGT was noticed for whole plant aqueous extract at all concentrations than that realized for leaf and root extracts (Figure 1). Nevertheless, significantly lower GI was recorded for whole plant and leaf aqueous extracts that were statistically similar. In the case of canola, GI was significantly affected by the aqueous extract concentration only (Table 2) and increasing extract concentration diminished GI of canola to a greater extent. Regarding FGP, an interactive effect was significant for both wheat and canola.
Leaf extract was more suppressive in wheat than whole plant and root extract at all concentrations. However, differences between whole plant and root extract were nonsignificant at a lower concentration $(2.5 \%)$. At a higher concentration, least suppression of FGP was observed for root extract (10\%). Different parthenium extract fractions at a lower concentration $(2.5 \%)$ had no significant effect on FGP of canola as compared with control. However, with any increase in further extract concentration, FGP was reduced to a greater extent by whole plant extracts, although at higher (10\%) concentrations a difference among whole plant, leaf, and root extracts for FGP was nonsignificant (Figure 1). Final germination was inhibited only when extract concentration exceeded $2.5 \%$ and was reduced by $44 \%$ (whole plant), 51\% (leaf) and $22 \%$ (root) with parthenium extracts applied at $10 \%$ concentrations. Such a reduction in the germination of canola was $51 \%, 48 \%$ and $52 \%$, respectively for above extract fractions. Higher extract concentrations (7.5 and 10\%) also led to mortality of germinated seedlings while at lower concentrations (2.5 and 5\%) seedlings were malformed and distorted.

\section{Experiment-II: Influence of soil applied aqueous extracts of parthenium on emergence and seedling growth attributes of wheat and canola}

Soil applied extract fractions of parthenium and their concentrations did not significantly influence TSE in both test species (Table 2). In wheat, $E_{50}$ was significantly affected by different extract fractions and concentrations. However in canola, only extract concentrations had significant effect on $\mathrm{E}_{50}$. Maximum delay in $\mathrm{E}_{50}$ was observed at highest extract concentration (10\%) in both species (Figure 2). Regarding MET, all the parthenium extract fractions were statistically similar with each other for wheat. Nevertheless, a significant $(p \leq 0.05)$ interaction between extract fractions and concentrations was noticed for MET of canola (Table 2). Significant interaction suggested that for any particular concentration whole plant extract had higher MET than leaf extract or root extract. In both test species, EI was significantly affected by parthenium extract fractions and different concentrations; 

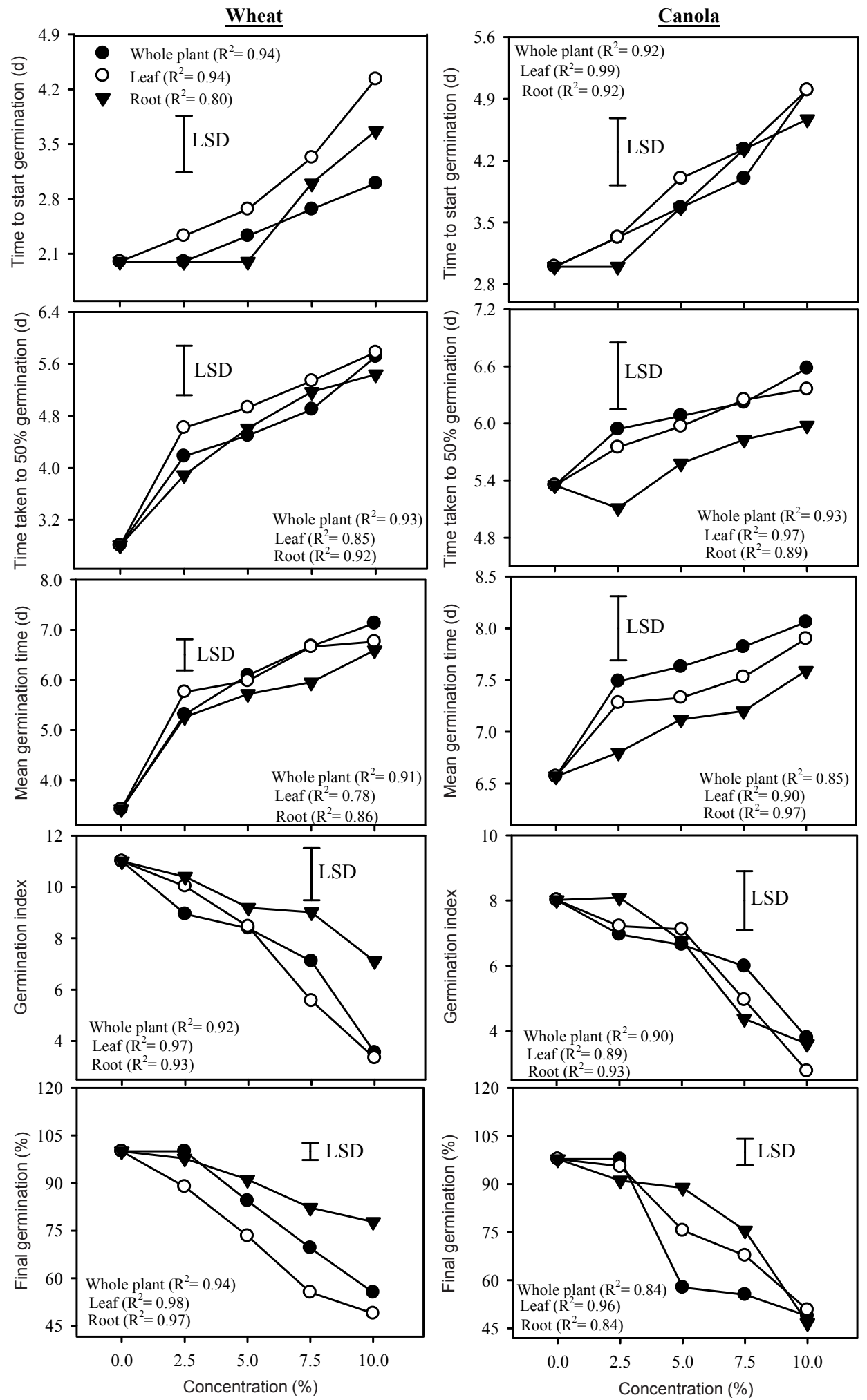

LSD is shown for the interaction between different plant fractions and aqueous extract concentrations.

Figure 1 - Influence of different plant fractions and aqueous extract concentrations of parthenium on different germination attributes of wheat and canola in Petri plates experiment. 
Table 2 - Summary of analyses of variance (ANOVA) for the influence of different plant fractions and aqueous extract concentrations of parthenium, and their interactions on germination/emergence, seedling growth, and biochemical attributes of wheat and canola in petri plates and soil-filled thermocol trays experiments

\begin{tabular}{|c|c|c|c|c|c|c|c|c|c|c|c|c|c|c|c|}
\hline \multirow{2}{*}{ Source of Variation } & \multicolumn{5}{|c|}{ Petri plates experiment } & \multicolumn{10}{|c|}{ Soil-filled thermocol trays experiment. } \\
\hline & TSG & $\mathrm{T}_{50}$ & MGT & GI & FGP & TSE & $\mathrm{E}_{50}$ & MET & EI & FEP & SL & RL & TDB & $\begin{array}{c}\begin{array}{c}\text { Chl. } \\
\text { contents }\end{array} \\
\end{array}$ & Phenolics \\
\hline \multicolumn{16}{|c|}{ Wheat } \\
\hline Concentration (Conc.) & $* *$ & $* *$ & $* *$ & $* *$ & $* *$ & $*$ & $*$ & $* *$ & $* *$ & $* *$ & $* *$ & $* *$ & $* *$ & $* *$ & $* *$ \\
\hline Extract fraction (Ext.) & $*$ & ns & $* *$ & $* *$ & $* *$ & ns & $*$ & ns & $* *$ & ns & $* *$ & $* *$ & $* *$ & $* *$ & $* *$ \\
\hline Conc. $\times$ Ext. & ns & ns & $*$ & $*$ & $*$ & ns & ns & ns & ns & $*$ & ns & ns & ns & $*$ & $*$ \\
\hline $\mathrm{CV}$ & 11.65 & 10.53 & 6.82 & 11.47 & 5.98 & 16.06 & 9.49 & 7.67 & 5.22 & 3.95 & 6.59 & 9.14 & 13.82 & 15.22 & 14.52 \\
\hline \multicolumn{16}{|c|}{ Canola } \\
\hline Concentration (Conc.) & $* *$ & $* *$ & $* *$ & $* *$ & $* *$ & ns & $*$ & $* *$ & $* *$ & $* *$ & $* *$ & $* *$ & $* *$ & $* *$ & $* *$ \\
\hline Extract fraction (Ext.) & $\mathrm{ns}$ & $*$ & $* *$ & ns & $* *$ & ns & ns & $* *$ & $* *$ & $* *$ & $\mathrm{~ns}$ & ns & $* *$ & $* *$ & $* *$ \\
\hline Conc. $\times$ Ext. & ns & ns & $*$ & ns & $* *$ & $\mathrm{~ns}$ & ns & $*$ & ns & $*$ & $\mathrm{~ns}$ & ns & $* *$ & ns & ns \\
\hline $\mathrm{CV}$ & 14.73 & 11.89 & 5.51 & 14.30 & 6.58 & 15.46 & 14.35 & 8.42 & 7.42 & 4.95 & 11.55 & 16.02 & 9.56 & 14.83 & 13.56 \\
\hline
\end{tabular}

** and * denote significance at the 0.01 and 0.05 probability levels, respectively. ns: nonsignificant, CV: Coefficient of variation, TSG: time to start germination, $\mathrm{T}_{50}$ : time taken to $50 \%$ germination, MGT: mean germination time, GI: germination index, FGP: final germination percentage, TSE: time to start emergence, $\mathrm{E}_{50}$ : time taken to $50 \%$ emergence, MET: mean emergence time, EI: emergence index, FEP: final emergence percentage, SL: shoot length, RL: root length, TDB: total seedling dry biomass, Chl: chlorophyll.

however, interaction between these two factors was nonsignificant (Table 2). Increasing extract concentration showed lower values of EI as compared with control (Figure 2). Extract concentrations of $2.5-7.5 \%$ showed statistically similar EI in wheat that declined further as the extract concentration was raised to $10 \%$ (Figure 2). Application of aqueous parthenium extract showed a slight yet significant reduction in FEP of wheat only when the extract concentration exceeded $5 \%$. A significant two-way interaction between parthenium fractions and extract concentration was observed regarding FEP of wheat and canola. A significant interaction $(p \leq 0.05)$ indicated that at low concentration $(2.5 \%)$, whole plant and leaf extract were not significantly different from each other (Figure 2). Whole plant and leaf extract also showed a statistically similar FEP suppression when applied at a higher concentration $(10 \%)$, yet such suppression was considerably higher than that realized for root extract of parthenium, particularly in canola (Figure 2).

A differential suppression of seedling growth of the test species was observed under the influence of different extract fractions of parthenium and their concentrations. Shoot length of wheat was significantly affected by parthenium extract fractions and their concentrations while shoot length of canola was only affected by the extract concentration (Table 2; Figure 3). Among extract fractions significantly $(p \leq 0.05)$ less shoot length of wheat was recorded for whole plant extract. All the extract concentrations reduced shoot length of wheat as compared with control and $10 \%$ concentration was more suppressive to shoot length in both species (Figure 3). Root length of both test species was decreased with increase in extract concentration. A lower extract concentration $(2.5 \%)$ did not significantly reduce root length of both test species over control. However, further increase showed a significant suppression of root length as compared with control (Figure 3). Reduction in shoot and root length was reflected in the form of a reduced seedling biomass. Increase in extract concentration was concomitant with decrease in seedling dry biomass of both test species. Leaf and whole plant extracts were more suppressive than root extract even at lower $(2.5 \%)$ concentration (Figure 3$)$. An interactive effect between extract fractions and concentration was significant $(p \leq 0.05)$ regarding seedling dry biomass of canola. Seedling dry biomass of canola did not vary significantly $(p \leq 0.05)$ among extract fractions at $10 \%$ concentration (Figure 3 ). 
Wheat
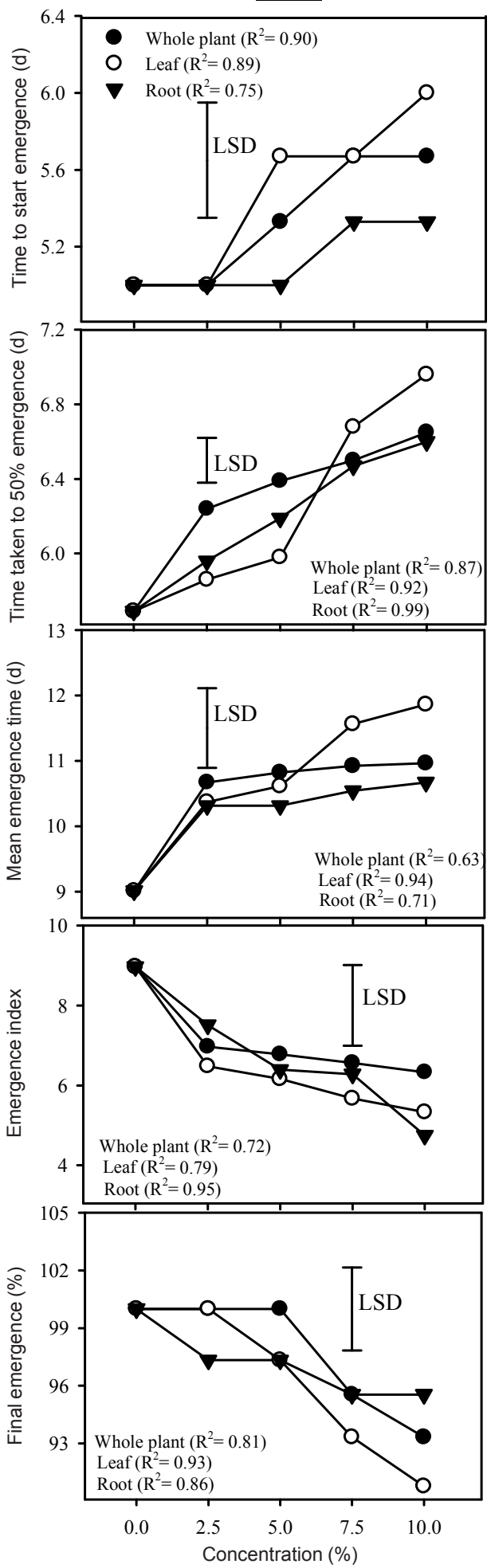

Canola


LSD is shown for the interaction between different plant fractions and aqueous extract concentrations.

Figure 2 - Influence of different plant fractions and aqueous extract concentrations of parthenium on emergence attributes of wheat and canola in soil-filled thermocol trays experiment. 
Leaf chlorophyll contents of wheat seedling were significantly affected by interaction between parthenium fractions and extract concentration (Table 2). At a low extract concentration $(2.5 \%)$, root extract did not reduce chlorophyll contents in wheat whereas whole plant and leaf extract showed a 32 and $37 \%$ reduction (Figure 4 ). At higher extract concentrations $(7.5$ and $10.0 \%)$, different plant fractions resulted in a similar level of suppression in chlorophyll contents. For canola, main effects of parthenium fractions and extraction concentrations were significant, while the interactive effect of these two factors was nonsignificant for chlorophyll contents. Leaf extract was more suppressive than root extract. Moreover, increasing extract concentration diminished chlorophyll significantly as compared with control (Figure 4). Averaged across different extract fractions, chlorophyll contents were reduced to the tune of 28 and $42 \%$ at an extract concentration of 2.5 and $5.0 \%$, respectively. Nonetheless, at higher concentrations (7.5 and $10.0 \%$ ), reduction magnitude corresponded to 64 and $68 \%$, respectively, and both concentrations were statistically similar. Each successive increase in extract concentration caused significant $(p \leq 0.05)$ increase in phenolic contents. Whole plant extract recorded more phenolic contents at all concentrations in wheat, while in canola, leaf extract shwoed
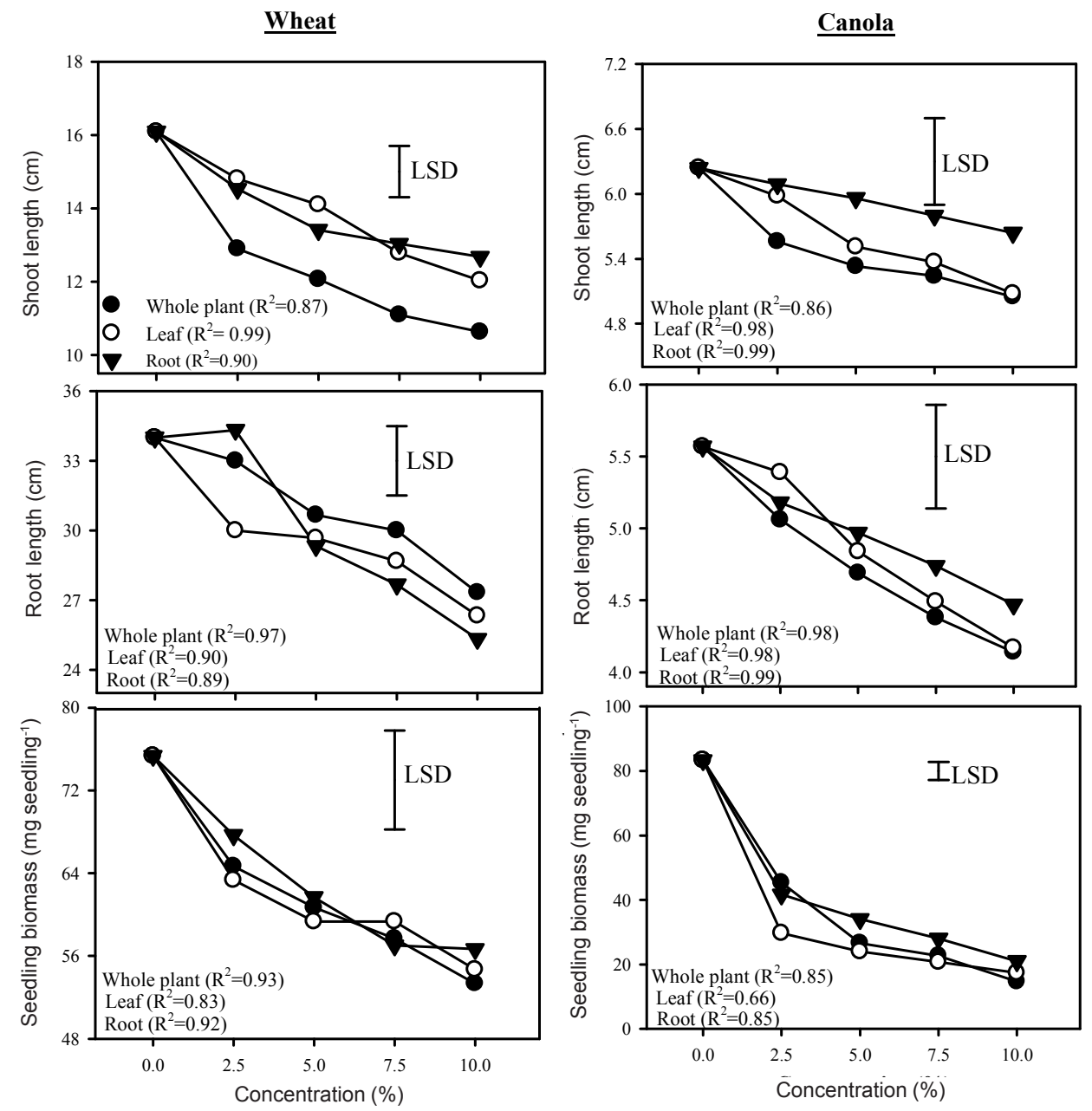

LSD is shown for the interaction between different plant fractions and aqueous extract concentrations.

Figure 3 - Influence of different plant fractions and aqueous extract concentrations of parthenium on seedling growth of wheat and canola in soil filled thermocol trays experiment. 



LSD is shown for the interaction between different plant fractions and aqueous extract concentrations.

Figure 4 - Influence of different plant fractions and aqueous extract concentrations of parthenium on total chlorophyll and soluble phenolic contents of wheat and canola in soil filled thermocol trays experiment.

more phenolic contents at $7.5 \%$ and $10 \%$ concentrations (Figure 4). The interaction between parthenium fractions and extract concentration regarding phenolic contents was only significant for wheat crop (Table 2).

\section{DISCUSSION}

The present study demonstrated that the aqueous extracts of parthenium were inhibitory to the germination and seedling growth of wheat and canola. Such an inhibitory activity of aqueous parthenium extracts may be due to the presence of suppressive allelochemicals in these extracts. Batish et al. (2002) have reported that extracts prepared from parthenium residues were rich in allelochemicals (phenolics) and exhibited phytotoxicity to the crops. Living as well as dead weed tissues of parthenium that are left in the soil after the completion of the life cycle can pose deleterious effects on subsequent crops by the release of allelochemicals upon decaying (Batish et al., 2007; Khaliq et al., 2015). These allelochemicals are reported to be present in almost all plant parts, including stems, leaves, flowers, buds, pollen grains, seeds, fruits, roots and rhizomes (Singh et al., 2003). However, differences are observed among species regarding their allelopathic potential and in their abilities to produce toxins in various parts (Qasem \& Foy, 2001; Tanveer et al., 2010), and parthenium is no exception (Khan et al., 2012). Different types of allelopathic compounds have been reported to be released from parthenium leaves (Swaminathan et al., 1990), stems (Mersie and Singh, 1988) and roots (Almodóvar-Vegat et al., 1988). Sesquiterpene, lactones and phenolics have been implicated for allelopathic activities of parthenium and such compounds are water soluble (Picman \& Picman, 1984; 
Swaminathan et al., 1990). Difference in the activity of aqueous parthenium extracts prepared from different fractions in suppressing germination of test species can be attributed to quantitative and qualitative differences in allelochemicals present in these extracts. Alterations in germination of the test species upon exposure to allelochemicals have been explained as a secondary expression of induced physiological and biochemical changes in cell ultra-structures, membrane integrity and permeability, de novo synthesis of certain compounds and enzymatic activity during germination (Weir et al., 2004; Gniazdowska $\&$ Bogatek, 2005). Rajendiran (2005) has reported a number of chromosomal aberrations in dividing cells under the influence of parthenium extract which increased significantly with increasing concentrations and durations of exposure.

Seedling growth of wheat and canola was adversely effected by various extract fractions of parthenium at different concentrations. Canola was more sensitive as compared to wheat crop. Maharjan et al. (2007) have reported that inhibition in seed germination of the crucifer species (Raphanus sativus, Brassica campestris and B. oleracea) was more pronounced as compared to Oryza sativa, Triticum aestivum, Ageratina adenophora and Artemisia dubia even at a low concentration. It was noted that species varied considerably in their sensitivity to aqueous extracts of parthenium (Belz et al., 2007; Rashid et al., 2008). Differential allopathic suppression in test species in the present study is also in line with the findings by Khaliq et al. (2015).

Soil application of aqueous extracts of different parthenium fractions reduced the leaf chlorophyll content in both test species (Figure 4). Decrease in chlorophyll content may be due to exposure of growing seedlings to phytotoxic compounds which are mostly phenolic in nature. Phenolic compounds are reported to decrease leaf expansion, chlorophyll content, photosynthesis and electron transport (Colpas et al., 2003; Norman et al., 2004). Phytochemical-mediated reduction in seedling photosynthetic pigments primarily due to phenolic acids has also been reported by Khaliq et al. (2012). Our results have revealed that whole plant and leaf extracts were more suppressive than root extract to both test species at all concentrations. It may be due to the presence of more phenolic contents in leaf than whole plant and root extracts (Table 1). Phytotoxicity of foliar parts of parthenium weed is well documented (Belz et al., 2007; Li $\&$ Jin, 2010). Xuan et al. (2004) have reported that foliar parts have more phytotoxicity because of greater biomass and metabolic activities. Tefera (2002) has reported that the germination of Eragrostis was more suppressed by the application of parthenium leaves and flower extracts as compared to stem and root extracts. Belz et al. (2007) showed that parthenin isolated and purified from the aqueous extract of parthenium leaves under laboratory conditions was significantly phytotoxic, and reduced the germination and seedling growth of wheat.

Some authors have reported that the inhibitory effects of aqueous extracts originated from changes in $\mathrm{pH}$ and osmotic potential and hence the raising concern about allelopathy and its ecological existence and relevance (Conway et al., 2002; Sisodia, 2008). In the present study, $\mathrm{pH}$ of extract fractions (whole plant, leaf and root) ranged from 6.6 to 7.8 (Table 1) and osmotic potential ranged from 0.04 to $0.20-\mathrm{Mpa}$, which are unlikely to cause an inhibitory effect on plant growth (Mersie \& Singh, 1987). Any growth reduction was presumably due to inhibitors. The amount of phenolics was also quantified in extracts from different fractions of parthenium and was in the order of leaves $>$ whole plant $>$ root extracts (Table 1). A 10\% leaf extract concentration showed about $1345 \mu \mathrm{g} \mathrm{mL} \mathrm{m}^{-1}$ of soluble phenolics.

Parthenium extracts suppressed the germination of test species to a greater extent when evaluated in Petri plates using filter paper as a substratum than when soil was used as a growth medium. Slope of lines indicating a drop in germination with increased extract concentration was steeper in Petri plates for different parthenium plant fractions (Figure1) as compared to the pot experiment (Figure 2). Even mortality of seedlings was observed in Petri plates but none in soil-filled pots. In the soil, allelopathic compounds are subjected to various transformations such

Planta Daninha, Viçosa-MG, v. 34, n. 1, p. 11-24, 2016 
as the utilization by soil microorganisms (Blum et al., 1999), chemical transformation (Okumura et al., 1999) and polymerization (Wang et al., 1986) among others acting either simultaneously or sequentially. These modify persistence, concentration, availability and biological activities of allelochemicals. Allelochemicals are also known to affect the physico-chemical soil properties and are qualitatively and quantitatively affected by these factors (Inderjit et al., 1996). Moreover, soil also possesses the ability to metabolize or detoxify allelochemicals. Such transformations are unlikely to occur in the Petri plates.

Previously, numerous studies (Inderjit \& Weston, 2000) have obtained contrasting results under controlled and natural field conditions. It is almost impossible to simulate exact field conditions in a bioassay; however in the present study, soil was also used as a growing medium with the objectives of maintaining the physical, chemical, and biological soil factors of the natural setting, as soil possesses the ability to detoxify allelochemicals. The aqueous parthenium extract contained appreciable quantities of phenolic compounds (most of the allelochemicals responsible for biological activity are phenolics in nature) but response was less as compared to that observed in Petri dish. There is strong reason to believe that contrary to petri dish, pot experiments using the extraction methods and concentrations are representative of what could happen in the field.

The present study concludes that the bioassay conducted under a controlled condition using filter paper as substratum can be misleading due to the overestimation of allelopathic response and potential of receiver and donor species. It implies that threshold concentrations of allelochemicals for test species in Petri plates are rarely reached under field conditions (soil) merely because such compounds will not accumulate to levels that can cause a significant allelopathic response. Moreover, the results demonstrated that leaf extracts of parthenium were most phytotoxic, while canola was the most susceptible test species in both Petri plates and soil.

\section{LITERATURE CITED}

ASLAM, F. et al. Differential allelopathic activity of Parthenium hysterophorus L. against canary grass and wild oat. J. An. Plant Sci., v. 24, n. 1, p. 234-244, 2014.

ALMODOVAR-VEGA, L. et al. Allelopathic effects of seven weed species on pumpkin (Cucurbita moschata) under greenhouse conditions. J. Agric. Univ. Puerto Rico, v. 72, n. 3, p. 491-493, 1988.

ASSOCIATION OF OFFICIAL SEED ANALYSIS - AOSA. Rules for testing seeds. J. Seed Technol., v. 12, n. 3, p. 1-112, 1990.

ASSOCIATION OF OFFICIAL SEED ANALYSIS - AOSA. Seed vigor testing handbook. Springfield, Illinois: 1983. (Contribution 32)

BATISH, D. R. et al. Allelopathic effects of parthenin against two weedy species, Avena fatua and Bidens pilosa. Environ.

Exper. Bot., v. 47, n. 1, p. 149-155, 2002.

BATISH, D. R. et al.Assessment of phytotoxicity of parthenin. Zeitschrift für Naturforschung, v. 62, n. 5-6, p. 367-372, 2007.

BELZ, R. G. et al. Residue allelopathy in Parthenium hysterophorus L. does parthenin play a leading role?

Crop Protec. v. 26, n. 3, p. 237-245, 2007.

BLUM, U. et al. Evidence for inhibitory allelopathic interactions involving phenolic acids in field soils: concepts vs. an experimental model. Crit. Rev. Plant Sci. v. 18, n. 5, p. 673-693, 1999.

COLPAS, F. T. et al. Effects of some phenolic compounds on soybean seed germination and on seed-borne fungi. Braz. Arch. Biol. Technol., v. 46, n. 2, p. 155-161, 2003.

CONWAY, W. C. et al. Potential allelopathic interference by the exotic Chinese tallow tree (Sapium sebiferum). Am. Midland Natur., v. 148, n. 1, p. 43-53, 2002.

DUKE, S. O. et al. Allelochemicals as herbicides. In: BONJOCH, N. P.; REIGOSA, M. J. (Eds.). EUROPEAN OECD ALLELOPATHY SYMPOSIUM: physiological aspects of allelopathy, 1., 2001,Vigo. Proceedings...Vigo: GAMESAL, 2001. p. 47-59.

ELLIS, R. A.; ROBERTS, E. H. The quantification of ageing and survival in orthodox seeds. Seed Sci. Technol., v. 9, n. 2, p. 373-409, 1981.

FAROOQ, M. et al. Thermal hardening: a new seed vigor enhancing tool in rice. J. Integ. Plant Biol., v. 47, n. 2, p. 187-193, 2005. 
FOY, C. L. How to make bioassays for allelopathy more relevant to field conditions with particular reference to cropland weeds. In: INDERJIT, R. K.; DAKSHINI, K. M. M.; FOY, C. L. (Eds.). Principles and practices in plant ecology: Allelochemical interactions. Boca Raton: CRC Press, 1999. p. 25-33.

GNIAZDOWSKA, A.; BOGATEK, R. Allelopathic interactions between plants. Multi site action of allelochemicals. Acta Physiol. Plant., v. 27, n. 3, p. 395-407, 2005.

INDERJIT, R. K.; WEINER, J. Plant allelochemical interference or soil chemical ecology? Perspect. Plant Ecol. Evol. Syst., v. 4, n. 1, p. 4-12, 2001.

INDERJIT, R. K.; WESTON, L. A. Are laboratory bioassays for allelopathy suitable for prediction of field responses? J. Chem. Ecol., v. 26, n. 9, p. 2111-2118, 2000.

INDERJIT, R. K. et al. Determination of allelopathic potential of a weed Pluchea lanceolata through a multi-faceted approach. Can. J. Bot., v. 74, n. 9, p. 1445-1450, 1996.

JAVAID, A.; RIAZ, T. Parthenium hysterophorus L., an alien invasive weed threatening natural vegetation in Punjab, Pakistan. Pakistan. J. Bot., v. 44, p. 123-126, 2012.

JAVAID, A. et al. Management of parthenium weed by extracts and residue of wheat. Afr. J. Biotechnol., v. 10, n. 65, p. $14399-14403,2011$.

KHALIQ, A. et al. Aqueous swine cress (Coronopus didymus) extracts inhibit wheat germination and early seedling growth. Inter. J. Agric. Biol., v. 15, n. 4, p. 743-748, 2013 b.

KHALIQ, A. et al. Residual phytotoxicity of parthenium: Impact on some winter crops, weeds and soil properties. Ecotoxicol. Environ. Saf., v. 122, n. 12, p. 352-359, 2015.

KHALIQ, A. et al. Swine cress (Cronopus didymus L. Sm.) residues inhibit rice emergence and early seedling growth. Philipp. Agric. Sci., v. 96, n. 4, p. 419-425, 2013 a.

KHALIQ, A. et al. Toxic action of aqueous wheat straw extract on horse purslane. Planta Daninha, v. 30, n. 2 , p. 269-278, 2012.

KHAN, N. et al. Assessment of allelopathic effects of parthenium (Parthenium hysterophorus L.) plant parts on seed germination and seedling growth of wheat (Triticum aestivum L.) cultivars. Pakistan J. Weed Sci. Res., v. 18, n. 1, p. 39-50, 2012.

KOHLI, R. K. et al. Status, invasiveness and environmental threats of three tropical american invasive weeds (Parthenium hysterophorus L., Ageratum conyzoides L., Lantana camara L.). Biol. Invas., v. 8, n. 7, p. 1501-1510, 2006.
LI, J.; JIN, Z. Potential allelopathic effects of Mikania micrantha on the seed germination and seedling growth of Coix lacryma-jobi Potential allelopathic effects of Mikania micrantha on the seed germination and seedling growth of Coix lacryma-jobi. Weed Biol. Manag., v. 10, n. 3, p. 194-201, 2010.

LICHTENTHALER, H. K.; WELLBURN, A. Chlorophyll and carotenoids: pigments of photosynthetic bio-membranes. In: PACKER, L.; DOUCE, R. (Eds.). Methods in enzymology. San Diego: Academic Press, 1987. p. $350-382$.

MAHARJAN, S. et al. Allelopathic effects of aqueous extract of leaves of Parthenium histrophrous on seed germination and seedling growth of some cultivated and wild herbaceous species. Sci. World, v. 5, n. 1, p. 33-39, 2007.

MARWAT, K. B. et al. Parthenium hysterophrous L. a potential source of bioherbicide. Pak. J. Bot., v. 40, n. 5, p. 1933-1942, 2008.

MERSIE, W.; SINGH, M. Allelopathic effect of parthenium (Parthenium hysterophorus L.) extract and residue on some agronomic crops and weeds. J. Chem. Ecol., v. 13, n. 7, p. 1739-1747, 1987.

MERSIE, W.; SINGH, M. Effects of phenolic acids and ragweed parthenium (Parthenium hysterophorus) extracts on tomato (Lycopersicon esculentum) growth and nutrient and chlorophyll content. Weed Sci., v. 36, n. 3, p. 278-281, 1988.

NORMAN, C. et al. Salicylic acids is an uncoupler and inhibitor of mitochondrial electron transport. Plant Physiol., v. 134, n. 1, p. 429-501, 2004.

OKUMURA, M. et al. Use of 14C-labeled alfalfa saponins for monitoring their fate in soil. J. Chem. Ecol., v. 25, n. 11, p. 2575-2583, 1999.

PICMAN, J.; PICMAN, A. K. Autotoxicity in Parthenium hysterophorus and its possible role in control of germination. Biochem. Syst. Ecol., v. 12, n. 3, p. 287-292, 1984.

QASEM, J. R.; FOY, C. L. Weed allelopathy, its ecological impacts and future prospects. J. Crop Prod., v. 4, n. 1, p. 43-119, 2001.

RAJENDIRAN, K. Mitodepressive effects of aqueous extracts of Parthenium hysterophorus L. on Vigna radiata (L.) Wilczek. Geobios, v. 32, n. 4, p. 237-240, 2005.

RANDHIR, R.; SHETTY, K. Developmental stimulation of total phenolics and related antioxidant activity in light and dark germinated maize by natural elicitors. Process

Biochem., v. 40, n. 5, p. 1721-1732, 2005. 
RASHID, H. et al. Effect of Parthenium hysterophorus L., root extracts on seed germination and growth of maize and barley. Am. J. Plant Sci. Biotechnol., v. 2, n. 1, p. 51-55, 2008.

SINGH, H. P. et al. Assessment of allelopathic properties of Parthenium hysterophorus residues. Agric. Ecosyst.

Environ., v. 95, n. 2/3, p. 537-541, 2003.

SINGH, H. P. et al. Phytotoxic effects of Parthenium hysterophorus residues on three Brassica species. Weed Biol. Manage., v. 5, n. 1, p. 105-109, 2005.

SISODIA, S. Allelopathic effect of Croton bonplandianum Baill. towards some weed and crop plants. Aligarh: Department of Botany, Aligarh Muslim University, 2008. p. 181-194,

SWAIN, T.; HILLIS, W. E. The phenolic constituents of Prunus domestica I-the quantitative analysis of phenolic constituents. J. Sci. Food Agric., v. 10, n. 1, p. 63-68, 1959.

SWAMINATHAN, C. et al. Allelopathic effects of Parthenium hysterophorus L. on germination and seedling growth of a few multipurpose trees and arable crops. Inter. Tree Crop. J., v. 6, n. 2/3, p. 143-150, 1990.
TANVEER, A. et al. Allelopathic potential of Euphorbia helioscopia L. against wheat (Triticum aestivum L.), chickpea (Cicer arietinum L.) and lentil (Lens culinaris Medic.). Turk. J. Agric. Forest., v. 34, n. 1, p. 75-81, 2010.

TEFERA, T. Allelopathic effects of Parthenium hysterophorus extracts on seed germination and seedling growth of Eragrostis tef (Zucc.) J. Agron. Crop Sci., v. 188, n. 5 , p. 306-310, 2002.

WANG, T. S. C. et al. The role of soil minerals in the abiotic polymerization of phenolic compounds and formation of humic substances. In: HUANG, P. M.; SCHNITZER, M. (Eds.). Interactions of soil minerals with natural organics and microbe. Madison: Soil Science Society of America, 1986. p. 251-281. (Special Publication Number 17)

WEIR, T. L. et al. Biochemical and physiological mechanisms mediated by allelochemicals. Curr. Opin. Plant Biol., v. 7, n. 4, p. 472-479, 2004.

WESTON, L. A.; DUKE, S. O. Weed and crop allelopathy. Crit. Rev. Plant Sci., v. 22, n. 3-4, p. 367-389, 2003.

XUAN, T. D. et al. Assessment of phytotoxic action of Ageratum conyzoides L. (Bill goat weed) on weeds.

Crop Protec., v. 1, n. 1, p. 1-8, 2004. 